Research article

\title{
Estimation of the real population and its impact on the utilisation of healthcare services in Mediterranean resort regions: an ecological study
} Emilio Perea-Milla*1, Sergi Mari Pons², Francisco Rivas-Ruiz ${ }^{1}$, Anna Gallofre2, Enrique Navarro Jurado ${ }^{3}$, Marco A Navarro Ales ${ }^{4}$, Alberto Jimenez-Puente ${ }^{1}$, Fidel Fernandez-Nieto ${ }^{5}$, Joan C March Cerda ${ }^{6}$, Manuel Carrasco ${ }^{1}$, Lydia Martin ${ }^{1}$, Damian Lopez Cano ${ }^{3}$, Gonzalo E Gutierrez ${ }^{3}$, Rafael Cortes Macías ${ }^{3}$ and Jose A GarciaRuiz $^{1}$

Address: ${ }^{1}$ Unidad de Apoyo a la Investigación, Evaluación y Contabilidad (Red IRYSS), Hospital Costa del Sol, Ctra Nacional 340, km 187, 29600 Marbella, Spain, 2l' Observatori Socioambiental de Menoría, Camí des Castell, 28 1r pis, 07702 Maó, Spain, ${ }^{3}$ Departamento de Geografía, Facultad de Filosofía y Letras, Universidad de Málaga, 29071 Málaga, Spain, ${ }^{4}$ Mancomunidad Municipios de la Costa del Sol Occidental, Urb. Elviria, N-340, Km. 190, 29600 Marbella, Spain, 5Delegación provincial de Salud de Málaga, C/Castelao 8, 29004 Málaga, Spain and ${ }^{6}$ Escuela Andaluza de Salud Pública, Campus Universitario de Cartuja s/n, 18080 Granada, Spain

Email: Emilio Perea-Milla* - eperea@hcs.es; Sergi Mari Pons - dir.obsam@cime.es; Francisco Rivas-Ruiz - frivasr@hcs.es; Anna Gallofre - adm.obsam@cime.es; Enrique Navarro Jurado - enavarro@uma.es; Marco A

Navarro Ales - medioambientemana@mancomunidad.org; Alberto Jimenez-Puente - ajpuente@hcs.es; Fidel Fernandez-

Nieto - jjf@infomail.lacaixa.es; Joan C March Cerda - joancarles.march.easp@juntadeandalucia.es; Manuel Carrasco - carrasco@hcs.es;

Lydia Martin - lydiamar@hcs.es; Damian Lopez Cano - gtci@uma.es; Gonzalo E Gutierrez - gonzalgf@hotmail.com;

Rafael Cortes Macías - rcortes@uma.es; Jose A Garcia-Ruiz - jgarcia@hcs.es

* Corresponding author

Published: 3I January 2007

BMC Health Services Research 2007, 7:13 doi:10.1186/1472-6963-7-13

This article is available from: http://www.biomedcentral.com/l472-6963/7//3

(c) 2007 Perea-Milla et al; licensee BioMed Central Ltd.

This is an Open Access article distributed under the terms of the Creative Commons Attribution License (http://creativecommons.org/licenses/by/2.0), which permits unrestricted use, distribution, and reproduction in any medium, provided the original work is properly cited.

\begin{abstract}
Background: The demographic structure has a significant influence on the use of healthcare services, as does the size of the population denominators. Very few studies have been published on methods for estimating the real population such as tourist resorts. The lack of information about these problems means there is a corresponding lack of information about the behaviour of populational denominators (the floating population or tourist load) and the effect of this on the use of healthcare services. The objectives of the study were: a) To determine the Municipal Solid Waste (MSW) ratio, per person per day, among populations of known size; b) to estimate, by means of this ratio, the real population in an area where tourist numbers are very significant; and c) to determine the impact on the utilisation of hospital emergency healthcare services of the registered population, in comparison to the nonresident population, in two areas where tourist numbers are very significant.
\end{abstract}

Methods: An ecological study design was employed. We analysed the Healthcare Districts of the Costa del Sol and the island of Menorca. Both are Spanish territories in the Mediterranean region.

Results: In the two areas analysed, the correlation coefficient between the MSW ratio and admissions to hospital emergency departments exceeded 0.9 , with $p<0.00$ I. On the basis of MSW generation ratios, obtained for a control zone and also measured in neighbouring countries, we estimated the real population. For the summer months, when tourist activity is greatest and demand for emergency healthcare at hospitals is highest, this value was found to be double that of the registered population.

Conclusion: The MSW indicator, which is both ecological and indirect, can be used to estimate the real population in areas where population levels vary significantly during the year. This parameter is of interest in planning and dimensioning the provision of healthcare services. 


\section{Background}

The demographic structure has a significant influence on the use of healthcare services, as does the size of the population denominators [1]. However, the vast majority of the studies published on the issue concentrate on factors referring to permanent populations. In areas such as tourist resorts, where large structural changes and annual fluctuations occur, the biggest problem lies in estimating the size of the population, before going on to consider its structure.

In the final decades of the 20th century, the coastal areas of developed countries in temperate climate zones advanced dramatically in both social and economic terms. In 1994, it was estimated that two thirds of the world's population lived within $150 \mathrm{~km}$ of the coast, and this value was expected to increase to three quarters by the year 2025 [2]. Beyond all doubt, current levels of economic globalisation have favoured the increased mobility of populations [3].

In Europe, the clearest manifestation of coastal development is to be found along the Mediterranean shores from Spain to Greece, a space in which an authentic urban continuum has been created everywhere physically possible [4]. In addition to concentration in terms of land occupation, tourism also presents a high degree of variability in time, with a marked increase in activity during the summer months; this fact heightens the impact on the environment and tends to produce a model that is economically fragile.

Very few studies have been published on methods for estimating the real population [5]. The earliest studies of the mobility of patients within developed countries highlighted disparities in health-influencing factors, among both the host and the incoming populations, together with variability in the treatment offered to the latter and increasing concern among their respective governments about healthcare costs [6-8]. The lack of information about these problems means there is a corresponding lack of information about the behaviour of populational denominators (the floating population or tourist load) and the effect of this on the use of healthcare services, leading to the seriously inadequate planning of healthcare resources. Indeed, this fact has been reported as impeding the estimation of rates of morbidity-mortality [9-12].

The goals of the present study are: a) To determine the real population in a popular tourist area; and b) to evaluate the impact on the utilisation of hospital emergency services by the permanent, registered population and by that of non-residents, in two popular tourist areas.

\section{Methods}

Design: An ecological study was designed. Location: The geographic areas analysed were the Costa del Sol Healthcare District (CSHD) and the island of Menorca, both of which are part of Spain and in the Mediterranean region. In the years 2001-2002, Menorca had an inter-censal population of 77,036 [13]; public healthcare resources consisted of three primary-attention clinics and one hospital (the Verge de Toro Hospital) in the capital, Mahon. During the inter-censal period of 2001-2002, the CSHD served a population of 271,257 and included a public hospital in the town of Marbella (the Hospital Costa del Sol) and seven primary attention clinics.

Instrumentation: The main variable analysed was the monthly generation of MSW in the two study areas during 2001, these data being supplied by the Association of Municipalities of the Western Costa del Sol (Mancomunidad de Municipios de la Costa del Sol Occidental) and by the Socio-Environmental Observatory (Observatorio Socio-Ambiental) of Menorca [14]. In estimating the Kg. of MSW generated per inhabitant per day in the CSHD, the Control Zone (CZ) was taken as all the inland municipalities in the province of Malaga (thus excluding the coastal municipalities, the city of Malaga and a nearby dormitory town); for these areas, the demographic structure was assumed to be stable, presenting no significant changes throughout the year. In the case of Menorca, the direct estimator used was the variable known as Human Pressure (HP), this variable being applicable thanks to Menorca's island identity, and to the fact that all entries and exits of travellers, by sea or air, are recorded daily. Thus, the total population of the island, including the permanent and the 'floating' elements, is always known. The $\mathrm{HP}$ variable enables us to obtain the value of the $\mathrm{Kg}$. of MSW generated per inhabitant per day for every month of the year, rather than having to use a single annual value.

An additional variable included was the maximum accommodation capacity, or the maximum number of beds available, estimated from the total recorded population plus the number of beds in registered accommodation facilities plus the number of second homes and unoccupied residential buildings (corrected by a factor of $10 \%$ to allow for speculative housing, this being defined as the flats and houses sold within a year of their purchase) multiplied by the mean number of occupants (3.1) [15].

Statistical Analysis: The ratios calculated were applied to the production of MSW in the two study areas in order to estimate the tourist load and its range; a statistical description was achieved by means of measures of central trend and of dispersion. We estimated the Pearson correlation coefficient (after testing for normality with the Kol- 
mogorov-Smirnov test), the coefficient of determination and the $95 \%$ confidence intervals for the estimates of the real population and the use of hospital emergency services during the year in which the study was carried out. For Menorca, these values were calculated for the relation between the MSW ratios and HP. The impact on the demand for healthcare services is described by the relative distribution of patients treated by hospital emergency services and by the patients' mean age, calculated monthly, the patients being differentiated by their place of residence within the reference healthcare district. The healthcare utilisation rate was calculated from the estimated real population (assuming a MSW production of $1.4 \mathrm{Kg}$. per inhabitant per day). The level of significance was taken as $\mathrm{p}<0.05$.

\section{Results}

The ratio of Kg. of MSW produced per registered inhabitant per day varied between 2.45 for the CSHD and 1.23 for the CZ. When the real population of the CSHD was estimated, based on three different ratios for the generation of MSW per inhabitant (1.2, 1.4 and $1.6 \mathrm{Kg}$./person/ day), the real population thus estimated exceeded the official values in every case. The estimated monthly population ranged from the 341,000 inhabitants calculated for the month of February, with a ratio of 1.6, to a maximum of 743,000 inhabitants in August, calculated using a MSW ratio of 1.2. The number of estimated inhabitants did not exceed the maximum accommodation capacity except the value calculated for the summer period with a MSW ratio of 1.2. (Table 1) Similar results were obtained for the estimated real population of Menorca using the HP parameter; during May-October, this value was double that of the official figure, while for the remaining months of the year the official value and the HP estimate coincided. The population level was minimum in January, with 70,000 inhabitants, and maximum in August with 177,000. During the months of January to March and in November and December, the estimated real population was less than the official recorded value.

The correlation coefficient between MSW and HP in Menorca was 0.99 (Table 2). The MSW/HP ratios obtained ranged between $1.38 \mathrm{Kg}$./person/day in December and $1.55 \mathrm{Kg}$./person/day in January. In both Menorca and the CSHD, the degree of correlation between the MSW and the monthly number of cases treated at the emergency department of the hospital in the study areas exceeded $0.90(\mathrm{p}<0.001)$.

With respect to the impact on health care services, the unregistered population constituted up to $34.9 \%$ of all urgent admissions during the month of August in the Costa del Sol Health District, and up to 26.1\% in Menorca in the same period. The mean age of non-residents decreased during the summer months in both areas, in comparison with that of the resident population, for whom the corresponding values remained stable (Table 3).

In the year 2001 for the CSHD, hospital emergency service facilities were used by 25.9 per 1000 of the recorded, permanent population, with a difference of 4.3 points between the months of maximum and minimum frequency (Table 4). The permanent population utilised hospital emergency service facilities about 3-4 times more

Table I: Estimate of the real population (1000s inhabitants) of the Costa del Sol Health District based on MSW in $200 \mathrm{I}$ and Menorca based on Human Pressure during 200I

\begin{tabular}{|c|c|c|c|c|c|c|c|c|}
\hline & \multicolumn{5}{|c|}{ Costa del Sol HD } & \multicolumn{3}{|c|}{ Menorca } \\
\hline & \multirow[t]{2}{*}{$\begin{array}{l}\text { Registered } \\
\text { Population }\end{array}$} & \multirow{2}{*}{$\begin{array}{c}\text { Max. } \\
\text { Accomm. } \\
\text { Capacity }\end{array}$} & \multicolumn{3}{|c|}{$\begin{array}{l}\text { Real population estimated with MSW ratio } \\
\qquad(\mathrm{kg} / \mathrm{hab} / \text { day })\end{array}$} & \multirow[t]{2}{*}{$\begin{array}{l}\text { Registered } \\
\text { Population }\end{array}$} & \multirow{2}{*}{$\begin{array}{c}\text { Max. } \\
\text { Accomm. } \\
\text { Capacity }\end{array}$} & \multirow[t]{2}{*}{$\begin{array}{l}\text { Human } \\
\text { Pressure }\end{array}$} \\
\hline & & & 1.2 & $\mathrm{I} .4$ & 1.6 & & & \\
\hline January & 264 & 631 & 455 & 390 & 341 & 75 & 190 & 70 \\
\hline February & 266 & 633 & 455 & 390 & 341 & 76 & 191 & 71 \\
\hline March & 267 & 634 & 486 & 416 & 364 & 76 & 191 & 72 \\
\hline April & 268 & 635 & 532 & 456 & 399 & 76 & 191 & 83 \\
\hline May & 269 & 636 & 519 & 445 & 389 & 76 & 191 & 118 \\
\hline June & 271 & 638 & 551 & 472 & 413 & 77 & 192 & $|4|$ \\
\hline July & 272 & 639 & 653 & 560 & 490 & 77 & 192 & 160 \\
\hline August & 273 & 640 & 743 & 637 & 557 & 77 & 192 & 177 \\
\hline September & 274 & 641 & 576 & 494 & 432 & 77 & 192 & $|4|$ \\
\hline October & 276 & 643 & 537 & 460 & 403 & 78 & 193 & 107 \\
\hline November & 277 & 644 & 487 & 417 & 365 & 78 & 193 & 73 \\
\hline December & 278 & 645 & 469 & 402 & 352 & 78 & 193 & 71 \\
\hline
\end{tabular}


Table 2: Bivariate correlation between the generation of Municipal Solid Waste (in tonnes) and Admissions to Emergency Healthcare Hospital Department for Healthcare Districts of the Costa del Sol and Menorca during 200I, and Bivariate correlation between MSW and Human Pressure with MSW ratios for Menorca during 2001

\begin{tabular}{|c|c|c|c|c|c|c|c|}
\hline & \multicolumn{2}{|c|}{ Costa del Sol HD } & \multicolumn{5}{|c|}{ Menorca } \\
\hline & MSW & Admissions & MSW & Admissions & MSW & $\mathrm{HP}$ & Ratio \\
\hline January & 16935 & 8094 & 3377 & 1714 & 3377 & 70088 & 1,55 \\
\hline February & 15275 & 7756 & 2915 & 1523 & 2915 & 71297 & 1,46 \\
\hline March & 18069 & 8534 & 3515 & 1837 & 3515 & 72096 & 1,57 \\
\hline April & $1914 \mid$ & 8859 & 3969 & 1777 & 3969 & 83065 & 1,59 \\
\hline May & 19312 & 8919 & 5439 & 2019 & 5439 & 118345 & $\mathrm{I}, 48$ \\
\hline June & 19845 & 9047 & 6128 & 2179 & 6128 & 141212 & 1,45 \\
\hline July & 24308 & 10190 & 7097 & 2400 & 7097 & 160269 & 1,43 \\
\hline August & 27628 & 11652 & 7726 & 2686 & 7726 & 177344 & $I, 4 \mid$ \\
\hline September & 20743 & 8206 & 6450 & 1981 & 6450 & 141383 & 1,52 \\
\hline October & 19982 & 8293 & 5274 & 1894 & 5274 & 106975 & 1,59 \\
\hline November & 17520 & 7479 & 3470 & 1532 & 3470 & 72591 & 1,59 \\
\hline December & 17437 & 7722 & 3030 & 1644 & 3030 & 70911 & 1,38 \\
\hline C. Correlation & 0,93 & $\mathrm{P}<0,001$ & 0,93 & $\mathrm{P}<0,001$ & 0,99 & $\mathrm{P}<0,00 \mathrm{I}$ & \\
\hline C.I. 95\% lower upper & 0,81 & 0,98 & 0,82 & 0,98 & 0,97 & 1,00 & \\
\hline C. Determination & 0,86 & & 0,87 & & 0,98 & & \\
\hline
\end{tabular}

Table 3: Relative distribution and mean age of patients and percentage on the total of monthly admissions treated at hospital emergency departments in the Costa del Sol Health District and in Menorca, during $200 \mathrm{I}$

\begin{tabular}{|c|c|c|c|c|c|c|c|c|}
\hline & \multicolumn{4}{|c|}{ Costa del Sol HD } & \multicolumn{4}{|c|}{ Menorca } \\
\hline & \multicolumn{2}{|c|}{$\begin{array}{c}\text { Emergency Admission of } \\
\text { Unregistered }\end{array}$} & \multicolumn{2}{|c|}{ Mean Age } & \multicolumn{2}{|c|}{$\begin{array}{l}\text { Emergency Admission of } \\
\text { Unregistered }\end{array}$} & \multicolumn{2}{|c|}{ Mean Age } \\
\hline & $\mathrm{n}$ & $\%$ & Resident & $\begin{array}{l}\text { Non- } \\
\text { Resident }\end{array}$ & $\mathrm{n}$ & $\%$ & Resident & $\begin{array}{l}\text { Non- } \\
\text { Resident }\end{array}$ \\
\hline January & 952 & $\mathrm{II}, 7$ & 37,6 & $4 I, 4$ & 41 & 2,6 & 41,6 & 57,0 \\
\hline February & 980 & 12,7 & 37,0 & 41,0 & 42 & 2,8 & 39,2 & 52,6 \\
\hline March & 1195 & 14,0 & 37,3 & $4 I, 4$ & 98 & 4,7 & 39,3 & 54,3 \\
\hline April & 1674 & 18,9 & 36,9 & 35,6 & 94 & 5,7 & 41,2 & 34,9 \\
\hline May & 1316 & 14,8 & 37,3 & 40,4 & 120 & 6,7 & 40,0 & 36,5 \\
\hline June & 1563 & 17,3 & 36,9 & 36,1 & 231 & 9,2 & 38,3 & 35,2 \\
\hline July & 2757 & 27,1 & 38,2 & 32,0 & 375 & 17,5 & 39,5 & 33,5 \\
\hline August & 4076 & 34,9 & 37,9 & 31,3 & 787 & 26,1 & 38,9 & 29,3 \\
\hline Septem ber & 1578 & 19,3 & 38,2 & 38,0 & 235 & 12,8 & 39,6 & 38,7 \\
\hline October & 1260 & 15,2 & 37,5 & 42,3 & 122 & 7,1 & 39,3 & 38,2 \\
\hline Novem ber & 948 & 12,7 & 38,4 & 41,0 & 62 & 3,4 & 39,7 & 51,9 \\
\hline Decem ber & 965 & 12,6 & 37,5 & 40,7 & 43 & 2,8 & 43,7 & 49,0 \\
\hline Average & 19264 & 18,4 & 37,5 & 36,6 & 2250 & 9,7 & 39,9 & 35,7 \\
\hline
\end{tabular}


frequently than the non-resident population, this proportion remaining basically constant during the year, although with a slight decrease during the months of July and August, coinciding with the changing ratio of the non-recorded to the official population (exceeding 1.0).

\section{Discussion}

The production of MSW and the population estimates based on this parameter are positively related to the utilisation of emergency healthcare services at hospitals in two geographic areas where tourist activity is significant. The frequency of use of hospital emergency service facilities varies during the year, as does the user profile.

Prior to obtaining the above correlations, we examined indirect indicators that might be used to establish the real population, such as the consumption of electricity, water, cement or hydrocarbon fuels, or the intensity of road traffic, but only the generation of MSW correlated strongly with variations in population and with the use of emergency healthcare facilities.

The choice of standard ratios for the generation of MSW to estimate population levels might introduce a degree of bias, as the areas analysed present different demographic and economic patterns. However, the ratios obtained in the Malaga Control Zone match the ratio calculated under the National Plan for Urban Waste 2000-2006 (1.23 vs. $1.20 \mathrm{Kg} . /$ person/day, respectively) [16], while in the coastal area of the same province this ratio was doubled. This phenomenon does not seem to be explained by a corresponding difference in income levels (in the province of Malaga, the weighted mean annual income in the $\mathrm{CZ}$ in 2002 exceeded 7,500 euros, while in the CSHD municipalities it exceeded 10,500 euros, only $40 \%$ higher). Nei- ther do we observe a systematic increase in the generation of MSW in different countries as income increases [17]. The ranges of ratios applied in this study are close to those measured in European Union countries in 2001, varying between $1.2 \mathrm{Kg}$./person/day (in Belgium, Portugal and Greece) and $1.6 \mathrm{Kg}$./person/day (in Germany, the United Kingdom and Holland). The mean value for the 25 countries of the EU is $1.4 \mathrm{Kg}$./person/day [18].

The estimates of real population based on the generation of MSW reveal a seasonal pattern: in the summer months, the estimated population doubles the official value. In the island of Menorca, seasonality is even greater, as in the first and fourth quarters of the year, the estimated and the officially recorded population values converge, while in the CSHD there exists an unrecorded population that remains stable during the winter months. This latter fact is consistent with the existence of different policies for tourism. On the island of Menorca, the traditional way of life, land and nature have not been displaced by mass tourism, while on the Costa del Sol there is a predominant service industry that is gradually becoming less seasonal by the integration of new areas of leisure activity.

Comparison of estimates of the real population with the utilisation of healthcare resources enables us to evaluate the consistency of these findings, as the greater the population to be attended, the greater the demand for healthcare. Nevertheless, it should be taken into account that the non-resident population normally suffers fewer health problems than the permanent population. The unrecorded population that is resident in winter is usually older, being mainly European pensioners. Among hospital activities, that of the emergency departments presents the highest degree of association with MSW production,

Table 4: Population of the Costa del Sol estimated using MSW ratio (I.4 kg./person/day) compared with the registered population and the utilisation of hospital emergency healthcare facilities per 1000 inhabitants per year in both geographic areas during $200 \mathrm{I}$

\begin{tabular}{|c|c|c|c|c|c|c|c|}
\hline & $\begin{array}{l}\text { Real Population } \\
\text { Estimated }\end{array}$ & $\begin{array}{c}\text { Registered } \\
\text { Population (RP) }\end{array}$ & $\begin{array}{l}\text { Unregistered } \\
\text { Population } \\
\text { (URP) }\end{array}$ & $\begin{array}{l}\text { Population } \\
\text { URP/RP }\end{array}$ & $\begin{array}{l}\text { Emergency } \\
\text { Admissions per } \\
\text { I000 RP }\end{array}$ & $\begin{array}{l}\text { Emergency } \\
\text { Admissions per } \\
1000 \text { RP }\end{array}$ & $\begin{array}{l}\text { Admissions } \\
\text { URP/RP }\end{array}$ \\
\hline January & 390.216 & 264.231 & 125.985 & 0,48 & 26,3 & 7,3 & 0,28 \\
\hline February & 389.678 & 265.508 & 124.170 & 0,47 & 27,3 & 8,5 & 0,31 \\
\hline March & 416.340 & 266.786 & | 49.554 & 0,56 & 26,7 & 7,7 & 0,29 \\
\hline April & 455.732 & 268.063 & 187.669 & 0,70 & 26,9 & 8,9 & 0,33 \\
\hline May & 444.976 & 269.340 & 175.636 & 0,65 & 27,3 & 7,3 & 0,27 \\
\hline June & 472.493 & 270.618 & 201.875 & 0,75 & 27,7 & 7,7 & 0,28 \\
\hline July & 560.096 & 271.895 & 288.201 & 1,06 & 26,5 & 9,3 & 0,35 \\
\hline August & 636.588 & 273.173 & 363.415 & 1,33 & 27,0 & 10,9 & 0,40 \\
\hline September & 493.873 & 274.450 & 219.423 & 0,80 & 24,1 & 7,2 & 0,30 \\
\hline October & 460.405 & 275.727 & 184.678 & 0,67 & 24,6 & 6,6 & 0,27 \\
\hline November & 417.146 & 277.005 & $|40| 4 \mid$. & 0,51 & 23,6 & 6,8 & 0,29 \\
\hline December & 401.777 & 278.282 & 123.495 & 0,44 & 23,4 & 7,6 & 0,32 \\
\hline Average & 462.221 & 271.257 & 190.964 & 0,70 & 25,9 & 8,3 & 0,32 \\
\hline
\end{tabular}


as the variability of outpatient treatment and hospital admissions is influenced by non-populational factors that are difficult to control, such as variations in healthcare personnel or changes in programmed activities. On the other hand, either of these populations (registered or unregistered) might seek other sources of care; the use of other health care facilities in primary care or the private sector might be alternative routes to care by these populations.

The correlation coefficients between the number of emergency admissions and MSW production (exceeding 0.90) indicates a strong degree of association and explains the high percentage of variability in the use of emergency healthcare facilities. It should be stressed that the correlation coefficient was identical in the two study areas. This finding is consistent with the association found between MSW production and overnight stays at winter sports resorts in France [5].

The non-resident population of the Costa del Sol is basically made up of three groups: 1) European pensioners, especially from the United Kingdom, Germany and Scandinavia, who stay in the area for several months a year; 2 ) tourists, both from other areas of Spain and from many foreign countries, who visit the area mainly in summer, but also during other periods, taking advantage of the mild climate; and 3) the population living in neighbouring municipalities who work in the area, mainly in the catering and construction industries. Rates of utilisation of the emergency department at the Hospital Costa del Sol are stable throughout the year, both among the recorded and the unrecorded populations.

The European pensioners make a similar use of healthcare facilities to that of the permanent local population in the same age group, although many of them are not officially registered as resident in Spain. Thus there is an added demand for healthcare and other services (municipal services, infrastructure and communications), the funding for which is provided on the basis of the officially recorded population. The relative increase in the rate of utilisation of healthcare facilities during the months of greatest tourist activity (July and August), together with the fall in the mean age of patients attended, reflect the profile of a younger non-resident population with a higher level of open-air leisure activities, associated with a different morbidity profile. No analysis of healthcare facility utilisation is given for the island of Menorca because the estimation method was influenced by the seasonal economic cycle characterising the island (i.e., the fact that a greater population decrease occurs during the winter), which resulted in negative values being obtained for certain months.
The satisfactory results of the correlation analysis between MSW and HP underline the consistency of MSW as an indirect indicator of the real population, given the reliability of the HP variable in Menorca. This is of great importance, as in the case of the island no physical access is possible except that included in evaluating the HP variable.

\section{Conclusion}

Indicators such as the generation of MSW, which are ecological and indirect, are useful for estimating the total population in areas in which there occur significant changes during the year, if other types of indicators are not available. Annual variations in MSW generation are closely linked to the utilisation of healthcare services, and particularly of emergency hospital services. Such an estimation method is of interest for the planning and dimensioning of the supply of healthcare services, and could be used in other countries in the UE, given the availability of UE MSW data within the EUROSTAT system. Future studies are required to further investigate the structural characterisation of the tourist load and of the needs for healthcare services, broken down by age and sex, among other categories.

\section{Competing interests}

The author(s) declare that they have no competing interests.

\section{Authors' contributions}

All authors contributed to the design of the study. Revision of the different versions of the study protocol: EPM, SMP, FFN, JAGR. Substantial contributions to the conception and design of the digital data record: EPML, FRR, AG. Acquisition of data and quality control: FRR, AG, GEG, MANA, FFN, JCMC. Analysis and interpretation of data: EPM, FRR, MC, LM. All authors have read and approved the final manuscript.

\section{Acknowledgements}

This study was funded by Fondo de Investigación Sanitaria (FIS) PI02I084. The study forms part of the IRYSS Network investigating the operations of healthcare services, which is funded by FIS G03/202.

\section{References}

I. Marion Buen J, Peiro S, Marquez Calderon S, Meneu de Guillerma R: [Variations in medical practice: importance, causes, an implications]. Med Clin (Barc) 1998, I 1 0:382-390.

2. Hinrichsen D: Coasts under pressure. People Planet 1994, 3:6-9.

3. MacPherson DW, Gushulak BD: Human Mobility and Population Health. New Approaches in a Globalizing World. Perspect Biol Med 200I, 44:390-40I.

4. Batisse M: Mending the Med. People Planet 1994, 3: I7- 18.

5. Olive F, Rey S, Zmirou D: [Industrial waste as indicator of population size: possible utilization in mountain resort tourist stations?]. Rev Epidemiol Sante Publique 1998, 46:299-304.

6. Crocetti E, Geddes da Filicaia M, Crotti N, Dell'Olio E, Spigai R: [The emigration of Italian patients to countries of the European Economic Community. Review of data published by the Ministry of Health]. Epidemiol Prev 1997, 2 I: 100-1 05. 
7. Sheaff R: Healthcare access and mobility between the UK and other European Union states: an 'implementation surplus". Health Policy 1997, 42:239-253.

8. Gushulak BD, Macpherson DW: Population mobility and health: an overwiew of the relationships between movement and population health. J Travel Med 2004, I I: I7I-174.

9. Librero J, Garcia Benavides F: [Validity of the municipality of residence in mortality statistics: findings based on municipality census update in $\mathbf{2}$ municipalities of the Valencian community]. Gac Sanit 1995, 9:232-236.

10. Librero Lopez J, Garcia Benavides F, Godoy Laserna C: [An analysis of mortality in small areas: the problem of residency]. Gac Sanit 1993, 7:169-175.

II. Esteva M, Tamborero G, Arias A, Seguí M, Llobera M: [Utilización de servicios sanitarios por la población flotante en Mallorca]. Rev Adm Sanit 2003, 3:44I-456.

12. Juaneda N, Cladera M, Esteva M, Tamborero G: [Impacto del turismo sobre la demanda de servicios públicos: el caso de los servicios sanitarios públicos]. Ann Tourism Res 2003, 5:149-162.

13. Instituto Nacional de Estadística: Censo de Población y Viviendas 200 INEBASE. Madrid 2004 [http://www.ine.es/inebase/index.html].

14. Consorci per a la Gestió de Residus Sòlids Urbans a Menorca. Consell Insular de Menorca: Dades de recollida de RSU a nivell municipal i mensual 1997-200I. Menorca 2002 [http://www.obsam.org/indicadors/ residus/sense seleccio/produccio RSU rebuig municipis.pdf].

15. Instituto de Estadística de Andalucía. Consejería de Economía y Hacienda: Sistema de Información Multiterritorial de Andalucía. Sevilla 2004 [http://www.juntadeandalucia.es/institutodeestadistica/sima web/ index.jsp].

16. Ministerio de Medio Ambiente: Plan Nacional de Residuos Urbanos (2000-2006). Madrid 2000 [http://www.mma.es/polit amb/planes/ index.htm].

17. Buenrostro O, Bocco G, Bernache G: Urban solid waste generation and disposal in Mexico: a case study. Waste Manag Res 200I, 19:169-176.

18. EUROSTAT: Eurostat Metadata in SDSS format. Municipal Waste. Bruselas 2004 [http://epp.eurostat.cec.eu.int].

\section{Pre-publication history}

The pre-publication history for this paper can be accessed here:

http://www.biomedcentral.com/1472-6963/7/13/prepub

Publish with Biomed Central and every scientist can read your work free of charge

"BioMed Central will be the most significant development for disseminating the results of biomedical research in our lifetime. "

Sir Paul Nurse, Cancer Research UK

Your research papers will be:

- available free of charge to the entire biomedical community

- peer reviewed and published immediately upon acceptance

- cited in PubMed and archived on PubMed Central

- yours - you keep the copyright
BioMedcentral 